\title{
TFTLRA CURUMUNÚN HUKUKI KONUSU
}

Doc. Dr. Nevzat TOROSLU

\section{A. GtRts}

Iftira suçu bütün anlamyla ele alındığında, iftira edici davianışı üç grup varlkk veya menfaatle çatışma halinde olduğu kolayca anlaşur. Nitekim iftirada, suçlama gerçek dışı olduğundan gerçeğe ilişkin kir varlık veya menfaat, kendisine isnad edilen suçu işlemediğinden bireye ait bir varlık veya menfaat ve başlamaması gereken bir koğuşturma başlayabileceğinden adliyenin idaresine ilişkin bir varlık veya menfaat ihlal edilmektedir. Iftira suçunun sosyal gerçeklik üzerindeki bu üçlü etkisi, hukukl konusunun bu varlık veya menfaatlerden hangisi olduğu kunusunda farklı anlayışların ortaya çıkmasına neden olmaktadır. Nitekim bu suçun anlamına ilişkin anlayışlardaki küçük farklılıklar, somut hukuk düzenini, sözü edilen varlık veya menfaatlerden birinin korunmasını yoğunlaştırmaya götürebileceği gibi, bu üç temel varhk veya menfaatten iirine dahil olan daha özel bir varlık veya menfaate daha fazla önem vermeye de götürebilir1.

Iftira suçunun hukukî konusunun bu suç tarafindan ihlal edilen ve yukarıda belirtilen hukukî varlık veya menfaatlerden hangisi olduğunu tesbit konusundaki güçlük, bu üç nevi varlık veya menfaatin ihlalinin su-

1 Nitekim roma hukuku iftirayı, objektif unsuru haksiz olarak verilecek cezanin Infan lle tamamlanacak olan diğer suçlar yönünden (orneğın adam öldürme, cebir kullanma, mulessir fiil) tesebbuls halinde kalmig belirli hareketlerin hukukt nitelendirilmesi (crimen sui generis) olarak tarif etmek suretiyle, haksız bir ceza mahklimiyetinin muhtemel infazina aģrık veriyordu. Cermen hukuku ise, daha çok iftiraya ugrayan bireyin serefini korumayı amaçliyordu. ' Nihayet günümüzdeki hukuk sistemleri, iftiraya öncelikle adliyenin idaresine karşı bir suç olarak anlamaktadırlar (PAGLIARO : I delitto di calunnia, Palermo 1961, s. 106-107).

Ancak bu suçun, çok eski saynlamayacak bazı yasamalarda da şerefe (Fransız ve Belçika Ceza Kanunlari) veya ammenin itimadina (Toskana

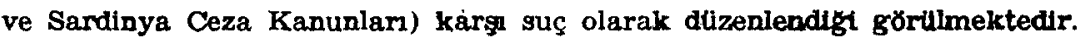


çun kanunî tipi yönünden birbirinden ayrilmamasından, yani her üç ihlâlin suçun oluşum sürecinin aynı safhasında gerçekleşmesinden de kaynaklanmaktadır. Nitekim üç nevi. varlığın ihlali de, belirli nitelikteki "suç isnad etme" veya "suçlama" da toplanmaktadır. Suçlama, sahte olduğu için gerçekliği, bir suça ilişkin olduğu ve adliyeye veya durumu adliyeye bildirmeye mecbur olan bir makama yöneldiği için adliyenin idaresini ve belirli bir kimseyi hedef aldığı için de bireyi ihlal etmektedir².

Öte yandan, bu suçu öngören normun, çeşitli yasamalardaki yerini göz önünde bulundurmak suretiyle, korumak istediği varlık veya menfaatler grubunun (veya kategorisinin) yukarıda belirtilenlerden hangisi olduğtanu tesbit etmek mümkün olsa bile, iftiranın sahtekârlık suçları veya şahsa karşı suçlar yahut adliyenin idaresine karşı suçlar arasındaki gerçek yerini, yani onun özel hukukî konusunu tesbit etmek sorunu, çözümlenmesi gereken bir sorun olarak kalacaktır.

Şu halde, iftira suçunun hukukî konusuna ilişkin soruna doğru bir cevap bulabilmek, sadece 285. maddede yer alan hükmün değil, iftirayı ilgilendiren bütün hükümlerin birlikte incelenmesi ile mümkün oabilecektir3. Oysa, çok defa bu hususun dikkate alınmaması sonucu, iftira suçu yönïnden korumanın konusunun hangi, varlık veya menfaat olduğu konusunda, yine çok defa hukukî varlık veya menfaat doktrininin gereklerine aykırı olan, değişik sonuçlara varılmıştır. Bu sonuçlar arasında metodolojik yönden sağlam bir seçim yapabilmek için, suçun hukukî konusunun hukukî öneminin nazara alınması zorunludur.

\section{B. IFTİRA CÜRMÜNÜ HİRDEN FAZLA HUKUKÎ KONULU SUC KABUL EDEN GÖRÜS}

Oldukca yaygın bir anlayıs, iftira suçunun adliyenin idaresine ilişkin bir menfaatten basska, zorunlu olarak, iftira edilene ait bir menfaati, yani iftiraya uğrayan bireyin şerefini veya muhtemelen hürriyetini de ihlal ettiğini savunmaktadır ${ }^{4}$. Ancak, bu şekilde düşünen yazarlardan bazlları daha da ileri giderek, iftira suçunun biri adaletin idaresine, diğeri iftira edilen bireye ait olmak üzere iki hukukî konusu ve dolayısıyla iki pasif

2 PAGLIARO : Il delitto, s. 113.

3 PANNATN : Calunnia e autocelunnia, Novissimo digesto Italiano, vol II, Torino 1957, s. 679; PAGLTARO : Il delitto, s. 113.

4 CARRARA : Programma del corso di diritto criminale, vol, V, Firenze 1911, s. 211, dipnot 3; GULLO : Il delitto di calunnia, Milano 1946, s. 8; MAGGLORE : Dritto penale, par. spec., vol II, Bologna 1960, s. 261; BOSCARELLI: Il delitto di calunnia verbale, Milano 1961, s. 41. 
süjesi bulunduğunu savunmaktadırlar ${ }^{5}$ : Antolisei'ye göre, iftiranın suç haline getirilmesinin nedeni veya amacı, adliyenin aldatılması ve yanlıs yola saptırılması ile suçsuz vatandaşın şerefinin ve muhtemelen hürriyetinin zarara uğratılması tehlikesini önlemektir. Bunun sonucu olarak, her ne kadar genellikle adlî faaliyetin korunmasına ağırlık verimekte ise de, korumanın konusu ve suçun pasif süjesi ikilidir 6 .

Hukukî konunun tesbit edilmesinin özellikle mağdurun rızası, şikâyet hakki, suç sayısı ve suçların tasnifi yönünden taşıdığı hukukî önem nazara alındığında, iftira suçunun hukukî konusunun ikili olduğunu kabul eden bu görüşün doğruluğunu şüphe ile karşllamak gerekir. Zira bir suçun fiilen birden çok varllk veya menfaati ihlal etmesi ve bu varlık veya menfaatlerin kanun tarafından nazara alınmis olması hallerinde bile, bunlardan sadece biri, normun sağladığı korumanın ve dolayısıyla suçun konusunun tesbiti yönünden belirleyici varlık veya menfaati oluşturur. Nitekim rıza göstermenin geçerli sayılması için, her bir suç yönünden, rızası suçu ortadan kaldıran nedeni oluşturabilecek bir süjenin belirlenebilmesi gereklidir. Bu nedenle suçun birden çok menfaati ihlal etmesi halinde, hukuken geçerli olan rıza, sadece suçu öngören normun amacınır. esas nüvesini temsil eden varlık veya menfaatin sahibinin rızasıdır. Örneğin memura hakaret suçunda (TCK. m. 266), memurun şerefinin de ihlal edilmesine rağmen, memurun rızası önem taşımaz; çünkï bu suçu ön gören norm esas itibariyle kamu idaresini korumak istemektedir. Benzeri düşünceleri, şikâyette bulunmayı meşrulaştırma ile ilgili olarak da tekrar etmek mümkündür. Nitekim, aksine bir düzenleme bulunmadığında, şikâyette bulunma hakkı, suç tarafından fiilen ihlal edilen çeşitli varlık veya menfaatlerden o suçu öngören normun esas itibariyle korumayı amaçladığı varlık veya menfaatin sahibine aittir. Yine, suçlarn tekliği veya çolkluğu sorununun çözümünde, aynı şekilde ihlâl edilen varlık veya menfaatler arasında bir seçimi, yani bunlardan birinin cezâ̂ korumanın ve suçun konusunu olușturduğunun kabulünü gerektirir. Örneğin vağma suçunda (TCK. m. 495) taşınır bir malın çok sayıda süjeden zorla alınmasının çok sayıda yağma suçunu oluşturması istenmiyorsa, malvarlığına veya buna ilişkin menfaate üstünlük tanınmalıdır. Nihayet bu gibi durumlarda suçların tasnifi yönünden de birinci derecede korunan bir

- ANTOLISEI : Manuale di diritto penale, par. spec., vol. II, Milano 1960, s. 729

Gullo da, iftira suçunda pasif süjenin ikili olduğunu kabul etmekteđir (II delitto, s. 8).

6 ANTOLdSEI : Manuale, par. spec., vol. II, s. 279. 
varlık veya menfaati seçmek zorunluluğu vardır. Aksi halde birden çok varlık veya menfaati ihlal eden suçların tasnifinde, çözümü imkânsız çelişkiler doğabilir?.

Hukukî konuyu oluşturan varlık veya menfaatin hukuk bilimindeki öneminden kaynaklanan bu sonuçlar, bizi suçun hukukî konusunun daima tek bir varlık veya menfaat olduğunu kabüle götürmektedir. Dolayısıyla bir suç fiilen birden çok varlık veya menfaati ihlal ettiğinde, bunlardan sadece biri, üstünlük ölçüsü gereği, o suçun hukukî konusunu oluşturur ve yine sadece bu varlık veya menfaatin sahibi o suçun pasif süjesidir. Suç tarafından ihlal edilen diğer varlık veya menfaatlerin sahipleri ise, ya suçun maddî konusu veya łavranışin (şuçun değil) pasif süjesi oldukları için yahut suçun maddi konusunu oluşturan șahıs veya şey ile hukukî veya fiilî ilişkisi bulunduğu için suç$\tan$ zarar gören olarak belirirler ve sadece muhakeme hukuku yönünden (örneğin, kamu davasına katılma ${ }^{8}$ ve şahsî hakk davası gibi ${ }^{9}$ ) bazı haklara sahip olabilirler.

\section{IFTtRA CURMÜNÜ TEK HUKUKÎ KONULU SUÇ KABUL EDEN GORUUSSLER}

\section{1 - Bireysel menfaat}

Bir anlaỳış iftira suçunun hukukî konusunun bireye ait bir menfaat olduğunu savunmaktadır. $\mathrm{Bu}$ anlayışın son zamanlardaki başlica savunucusu Pagliaro, bir suçun birden fazla menfaati ihlal etmesi halinde, normun sağladı̆̆ı korumanın konusunun bu menfaatlerden hangisi olduğu sorununun çözümlenebilmesi için, söz konusu menfaatlerin hukukî konu kavramının özellikle mağdurun rızasına, şikâyete ve suç sayısına ilişkin önemi yönünden ele alınması gereğine işaret etmekte$\operatorname{dir}^{1 \theta}$.

Yazara göre, incelenmesi gereken ilk husus, suçlananın rızasının, iftira suçunu ortadan kaldırması imkânıdır. Bunu ortaya koyabilmek için, İtalyan Ceza Kanununun "kendi kendine iftira" yı ayrı bir suç olarak tarif etmiş olmasından hareket edilebilir. Suçlanmaya rıza gös.

I PAGLIARO : In delitto, s. 110, 111.

8 Bu konuda bak. KUNTER: Muhakeme Hukuku Dalı olarak Ceza Muhakemesi Hukuku, Istanbul 1981; s. 173 vd; TOSUN : Türk Suc Muhakemesi Hukuku Dersleri, c. I, Istanbul 1981, s. $165 \mathrm{vd}$.

- Bu konuda bak. KUNTER : Muhakeme Hukuku, s. 160, 161, 174, 175.

10 PAGLIARO : Il delitto, s. 11.4 vd. 
teren kimse, kendisinin suçlanmasını istemektedir; çünkü rıza gösterme bir isteme biçimidir. $\mathrm{Bu}$ itibarla kendi kendine iftiraya ilişkin kanunî tip sübjektif unsur yönünden gerçekleşmiştir. Dolayısıyla, suçlananın bu suç iradesini bir başka süjenin gerçekleştirmesi halinde, kendi kendine iftiraya iştirake ilişkin hüküm her ikisi için de uygulanabilir hale gelmiştir. Şu halde suçlananın rızasının, iftira suçunun oluşmasunı önleyeceğini kabul etmek gerekir ${ }^{11}$.

Pagliaro'nun bu konuda üzerinde durduğu ikinci husus, iftira suçunun bütün unsurlarına sahip suçlamanın yurt dışında işlenmiş olması halinde (örneğin, suçlamanın, devamlı veya geçici olarak yabancı bir ülkede bulunmasına rağmen adlî makamların fonksiyonuna sahip bir süjeye veya durumu bu süjeye bildirmek zorunda olan bir makama bildirilmesi halinde) suçlananın İtalyan Ceza Kanununun 9/2. ve 10/1. maddelerinde öngörülen "geri alınamayan şikayet" te (istanza) ${ }^{12}$ bulunup bulunamayacağı sorunudur. Bu konuda açlk bir düzenlemenin mevcut olmadığını, ancak bu müiesseseyi biçimlendiren amaçsal esaslardan hareketle olumlu bir sonuca varllabileceğini belirten' yazar şöyle demektedir : Geri alınamayan şikâyet (istanza) müessesi, yabancı ülkede işlenen fiillere karşı devletin normal sayılan ilgisizliği ile bir vatandaşın zarar görmesi halinde istisnaî olarak ortaya çıkabilen cezalandırma şeklindeki ilgisini dengelemeyi amaçlamaktadır. Burada, hukukî varlık veya menfaatin sahibini tesbite yarayan basska unsurların bulunmaması halinde, vatandaşın korunması lehindeki yorumun üstünlük kazanması gerekir. Bu durumda zarar görmesi muhtemel olan kamusal menfaatlerin cezaî korumadan yoksun kalacağı söylenemez; zira adalet bakanunın talebi ile cezalandırma yoluna gitmek daima mümkündür. Şu halde, iftira suçunun pasif süjesinin kim olduğu konusunda karar verebilmek için gerekli olan diğer unsurlar bu suçun düzenlenmesinden elde edilemese dahi, sadece "geri alınamayan şikâyet" (istanza) müessesesi, söz konusu suçun pasif süjesinin suçlanan kişi olduğunu göstermeye yeterlidir ${ }^{13}$.

Pagliaro'nun, bu iddiasını desteklemek için, üzerinde durduğu üçüncü husus ise, birden çok suçsuz kimsenin bir tek suçlama ile suçlanmasının tâbi olduğu rejimdir. Nitekim yazara göre, bu suçun hukukî konusu kamunun itimadı veya adliyenin idaresi olsayd,, itham edilen-

11 PAGLIARO : Il delitto, s. 116.

12 Bak. LEONE : Istituzioni di diritto processuale, vol I, Napoli 1965, 8. 337 vd.

13 PAGLIARO : Il delitto, s. 117, 118. 
lerin çokluğuna rağmen bu menfaatlerin ihlali tek kalırdı ve dolayısıyla suçlama tek oduğunda (örneğin. birden çok süjeye karşı bir tek ihbar veya birden çok süje aleyhine suç izleri uydurma gibi) bir tek suç işlenmiş sayllurdı. Oysa doktrin ve uygulama, bu hallerde birden çok suçun varlığını kabul etmekte; sadece fikrî içtima mı, yoksa müteselsil suç mu olduğunu tartışmaktadır ${ }^{14}$. Ancak bir davranışın tek suç sayılmasını gerektiren tek davranış olarak anlaşılması için gerekli şartların bulunmasına rağmen, suçın pasif süjesinin sayısı ile ilgili olarak birden çok suçu oluşturması, sadece hayat, fizikî bütünlük ve șeref gibi esas itibariyle bireysel varlkklarin ihlal edilmesinde söz konusudur. Oye ise doktrin ve uygulamanın, suçun hukukî konusunun adliyenin idaresi olduğunu kabul ettikten sonra, birden çok süjenin bir tek suçlama ile suçlanması halinde, suçlanan süje sayısınca iftira suçunun gerçekleştiğini kabul etmesi bir çelişkidir. İşte bu çelişki dahi iftira suçunun şahsa karşı bir suç olduğunun çok açık bir belirtisidir ${ }^{15}$.

Pagliaro, bu üç esastan hareketle, iftira suçunun hukukî konusunun, sadece bir masumun ceza koğuşturmasına uğramamasındaki menfaati olduğu sonucuna varmaktadır. Yazara göre, suçsuz bir şahsın ceza koğușturmasına uğramamasında devletin de adlî yetkileri yönünden bir menfaati vardur; ancak bireyin menfaati ile adliyenin idaresine ilişkin bu menfaat arasındaki ilişki, kamusal haklar yönünden bireyin menfaati ile devletin menfaati arasındaki ilişkinin aynısıdır; yani doğrudan doğruya korunan menfaat bireyin menfaatidir; ancak bu koruma, bireyin menfaatine tekabïl eden ve devlete ait olan bir menfaat de göz önünde tutularak öngörülmüsstür ${ }^{16}$.

Ancak, iftira suçunun hukıkî konusunun adliyenin idaresine ilişkin bir menfaat değil de, suçlanan şahsa ait bir menfaat olduğunu savunan bu görüşün dayandığı gerekçeleri, en azından kanunumuz yönünden, söz knnusu iddiayı haklı kllacak nitelikte kabul etmek mümkün görülememektedir.

Bir kere, mağdurun rızası ile ilgili iddialar gerçeğe uygun değildir. Burada, her şeyden önce mağdurun rızasının, hangi hallerde ceza normu ile korunan menfaati ortadan kaldırdığı ve işlenen fiili zararsız hale getırdiği sorunu karșımıza çıkmaktadır. İtalyan Ceza Kanununun 50. maddesi "Üzerinde geçerli bir şekilde tasarrufta bulunabilen şahsın im-

14 PAGLIARO : $\mathbb{I}$ delitto, s. 118.

15 PAGLIARO : Il delitto, s. 118.

16 PAGLIARO : II delitto, s. 121, 122. 
zasi ile bir hakka zarar veren veya tehlikeye koyan kimse cezalandirlmaz." demektedir. Bu hükümden hareketle, rızanın, üzerinde etkili olabileceği bir konuya, yani sahibinin geçerli şekilde tasarruf edebileceği bir hakka, daha doğru bir değişle, hukukî varlık veya menfaate ilişkin olması gerektiği söylenebilir. Böylece hangi hukukî varlik veya menfaatlerin (yahut haklarin) hukuken geçerli şekilde tasarruf edilebilir olduğunun tesbiti sorunu ortaya çımaktadır.

Her ne kadar Türk Ceza Kanununda mağdurun rızasının hukuka aykırılığa etki edip etmediği konusunda, Italyan Ceza Kanununun 50. maddesinde olduğu gibi, genel bir hüküm mevcut değil ise de, kanunun bir çok maddesinde mağdurun rızasının bulunmamasının veya failin suçtan zarar gören kimsenin (pasif süjenin) rızașına aykırı hareket etmesinin suçun kurucu unsuru saynldığı görülmektedir ${ }^{17}$. Su halde mağdurun rızasının hangi hukukî varlık veya menfaatler (yahut haklar) yönünden geçerli olduğu sorunu Türk Ceza Kanunu açısından da söz konusudur.

Doktrinde çok tartışmalh olan bu konunun derinlemesine bir incelemesini yapmaksızın, şu kadarını belirtmek gerekir ki, bir varlık veya menfaatin tasarruf edilebilir olup olmadığını tesbit etmek için, bir yandan doktrinde ileri sürülen genel ilkeleri, diğer yandan da belli bir varlık veya menfaatin kanunî tipteki değerlendirilişini göz önünde bulundurmak, bu varlık veya menfaatin hukuk düzeni tarafından tasarruf edilebilir olarak değerlendirilip değerlendirilmediğini her norm yönünden araştırmak gerekir ${ }^{18}$.

$\mathrm{Bu}$ durumda, iftira suçunun hukukî konusunun, Pagliaro'nun iddia ettiği gibi, bir masumun ceza koğuşturmasına uğramamasındaki menfaati olduğu kabul edilse bile, bu menfaatin hukuken geçerli şekilde tasarruf edilebilen yani suçlananın rızası ile korunmaya değer olmaktan çıkan bir menfaat olduğu söylenemez. Nitekim İtalyan Ceza Kanunu, 369. maddesinde kendi kendine iftirayı da cezalandırmak suretiyle, bir kimsenin kendisini ceza koğuşturmasına uğratamayacağını, yani böyle bir koğuşturmaya uğramamadaki menfaati üzerinde hukuken geçerli bir tasarrufta bulunamayacağını kabul etmektedir.

17 Orneğin TCK nun 182, 193, 471 ve 491. maddelerinde olduğu gibi.

18 PISAFIA : Introduzione alla parte speciale del diritto penale, vol. I, Milano 1948, s. 153; TOROSLU : Cürtłmlerın Tasnift Bakımından Suçun Hukukt Konusu, Ankara 1070, s. 236, 237. 


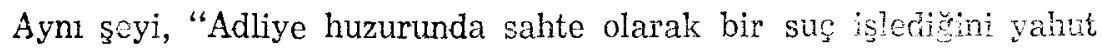
bir suça istirak eylediğini söyleyen kimse"yi cezalsndman (TCK.nu: 283/2) buna kargsilk, Italyan Ceza Kanununun aksire, koodi kendine iftira suçunun failin kendisinin veya bir yakininin hïrryeino veya şerefine yönelik ağır bir zararı önlemek amacryla işonmiş ofrasi halini cezasızlık sebebi saymayan Türk Ceza Kanunu yönünden $s 6 y$ lomok çs daha kolaydrr.

Yine, suçlananin suçlamaya riza göstermesi halinde, herdi trondine

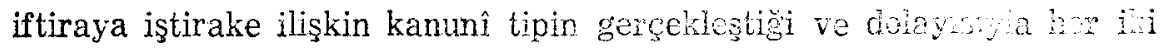
failin de artık iftiradan değil, fakat istirak halinde kond tron thiradan sorumlu olacağ iddiası da tatmin edici gözükmencktcąs. Nitolin bu konu herşeyden önce iştirairten söz edilebilmesi için croin olan manevî unsurun neden ibaret bulunduğu sorunu ile ilghilid:. Binhtig üzere bir kısim yazarlar, bu unsurun gergekleşmesi için bagtamn hareketine iştirak bilincini ycterli görürken, bazlan indelth briesmesinden söz etmektedirler ${ }^{19}$. Doğruluğuna inandŭğmaz aningis, istrakin manevî unsurunu, suçu oluşturan fiile iştirak etmek, onu birilłte gerçeklestirmek iradesi olarak kabul etmełtedir ${ }^{20}$. Buna göre istirakin manevi unsuru hedef alinan suçun gerçezleşmesi icin diser sahem yaptığı, yapmakta olduğu ve yapacă̆ı hareketleri lilmei ve a tesavvur

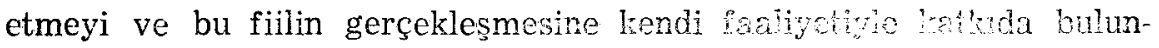
mak iradesini gerektirir. Bu durumda sucianms omar? sadece maa göstermenin, kendisinin suçanmasmi irade etmeli, istemel anlamina geldiğini, dolayısıyla iştirakın manevî unswunun oiuşư̌̆unu söylemek,

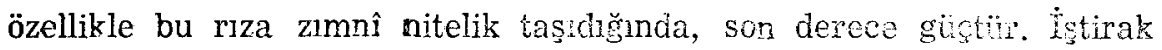
tiplerini belirtmeksizin, sadece "birden fazla sahsm ayn suça iştira etmesi"ni yeterli gören İtalyan Ceza Kanunu (m. 110) yöninden söz konusu olabilen bu güçlük, çeşitli iştirak biçimlerini bir bir belirtckn Türk Ceza Kanunu (m. 64, 65) yönünden daha da artmalstadir. Nitekim bir kimsenin bir suça iştirak cttiğini kabul etmek için, söz konusu kişinin 0 suçun işlenmesine kanunda belirtilen iştirak tiplerinden birine uygun bir hareketle katılmış olması gerekmektedir²1. Sucsuz olduğı

19 Bu konuda bak. ANTOLISEI : Manuale di dirito penale, porte gensrale, Milano 1963, s. 419 vd.; DÖNMEZter - ERMAN : Nazari ve Tałbiri Cez̃ Hukuku, c. II, Istanbul 1981, s. 583 vd, EREM : Türk Ceza IKukuku, c. I, genel hükumler, Ankara 1976, s. $399 \mathrm{vd}$.

20 ANTOLISET : Manuale, par. gen, s. 420.

21 Iģtirak biçimleri hakkında bak. M[ANZINT: Trattoto di diritto nenale italiano, vol. Ir. Torino 1926, s. 313 vd.; EREM : Türk Ceza Hukuku, c. I, s. 429 vd; DÖNMEZER - ERMAN age., c. II, s. 635 vd. 
halde kendisinin başkası tarafından suçlanmasin meksizin veya bu konuda verilen kararı takviye etmaksizin, sadece böyle bir suçlamaya rıza gösteren kimsenin har^ketini iştirak biçimlerincien birine sokmak mümkün gözükmemektedir ${ }^{22}$.

Öte yandan, iftira suçunun ülke dışında işlenmiş olması halinde iftira edilen kimsenin geri almamayan şikâyette (istanza) bulunabileceği, dolayısıyla suçun pasif süjesinin bu kişi olduğu, yani suçun hukukî konusunu bu kişiye ait bir menfaatin oluşturduğu iddiasına gelince : Bilindiği üzere Ittalyan Ceza Kanunu, yabancı üßkede bir cürüm işleyen vatandaşı ve yine yabancı ülkede Ittalyan Devleti veya vatandaşı za-

22 İtalyan hukuku yönünden de, suçlanonın suçlenmaya riza göstermesi halinde suclama hareketini gerçekleştirenin ve suclananın kendi kendine iftiraya istirakten sorumlu oinalar, yani bu durumda ifoisa sumun ceçil, kendi Jendine iftira suçunun oruşması, I alyan Ceza Kanumunda kendi

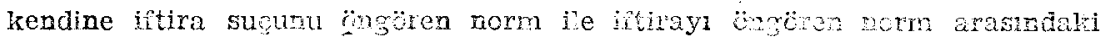
bzrllik - genellik likgkisinden kaynaklandiğı ileri sürülmektedr. Nitekim Itaiyan Ceza Kanununun iftirayı öngören 368. maddesinde yer alan formül ile kendi kendine iftirayı öngören 369. maddesinde yer alan formül karş1laştırılağında, kexil kendine iftira suçuna ilişin hürür rercut oimasayd, bir suc iģiediğini adî makama veya durumi adì makama iletmekle yürtümiü olan bir başira makema sohte ciarak beyan ecien lrmo - bevanda bulunan hakkinda o fiile ilgili clarak başamiş bir muhairene sirasinda yapilmamig olmas? gartiyle - iftira sucunden sorumiu olabilece varmak mümkündür. Gercekten de 369 . madojede "anonim veya sahte ad altında bir yazı ile yapllmıß̧ oisa dahi, bir önceki madcede (yaai iftirayı düzenleyen maddede) belirtien makamlarden herhangi birine beyaucia bulunmak suretiyle iģlenmediğini bildigi bir suç ile veya baskikara tarafmdan i§̧ienmiş olan bir suç ile kendisini suclayan" kimsenin davranış olarak beljrtilen davranışta, 3e8. maddede "anonim veya sahte ad altında olsa dahi, adlî makama veya durumu bu makama iletmekle yuktumü olan bir baska makama yönelik ihbar, şikeyet, talep veya geri ainamejan şikayet (istanza) ile masum olduğunu bildiği birini bir suçla suçayan" kimsenin davranı̧ olarak belirtilen davranışn butü unsurlamm teghis etmek mümkün gözükmektedir. Bir başła değişle, suçlanan ile suçlayanın aynı şahıs olmasının ortaya koyduğu özelleştirici unsur nedeniyle, kerçi kendine ifftiraya ilişkin kanunî tị iftiraya ilişkin kanunî tipe nazaran özel bir kanunî tip olarak belirmektedir (BOSCARELLI: Il delitto, s. 43, 44)

Burada ihbar, şikâyet, talep veya gexi alınamayan șikâyet (istanza) ile bir kimsenin kendisine iftira edemeyeceği ileri sürilemez. Zira bir kimsenin kendisini bir suç ile suçlayan beyanın ihbar saymayı engelliyen herhangi bir mantık veya hukuk kural mevcut değildir. Ote yandan kend: kendine iftira cürmünün, sahte bir isimle olması şartiyle, şikâyet, tałep veya geri alınamayan şikâyetle işlenebileceğini de kabul etmek gerekir (BOSCARELLI : s. 44, dipnot 66). 
rarına bir cürüm işleyen yabancının, diğer bazı şartlardan ayrı olarak, ancak adalet bakanının talebi yahut zarar gören şahsın geri alınamayan șikâyeti (istanza) veya normal şikâyeti (querela) üzerine cezalandırılabileceğini hükme bağlamaktadır (m. 9/2, 10/1). Burada talep, geri alınamayan şikâyet ve normal şikâyet müesseselerinin karışılığa sebep olacak şekilde birbirlerine adeta eşit kılınmalarının şu şekilde yorumlanması gerekir: Suc devlete veya topluma ait bir menfaati ihlal ediyorsa, koğuşturmanın uygunluğunu en iyi șekilde değerlendirebilecek kamusal organ olan adalet bakanının talebi gerekir. Buna karşılık suç bireye ait bir menfaati ihlal ediyorsa, resen koğuşturulması gereken veya şikâyet üzerine koğuşturulan bir suç olmasına göre, ya zarar gören şahsın (pasif süjenin) geri alnamayan şikâyeti (istanẓa) veya normal şikâyeti (querela) aranacaktır²3.

Şu halde, iftira suçunun hukukî konusunun, bu suç tarafından ihlal edilen menfaatlerden (adaletin idaresine veya suçanan masum şahsa ait menfaatlerden) hangisi olduğunu önceden tesbit etmeksizin, sadece söz konusu suçun yurt dışında işlenmiş olması halinde iftira edilen şahsin geri alınamayan şikâyette (istanza) bulunabileceğini söyleyip, bundan hukuki konunun bu şahsa ait bir menfaat olduğu sonucunu çıkarmak, isbat edilmesi gerekeni isbatın dayanağı clarak kabul etmek seklindeki mantık hatasına düşmek anlamına gelecektir. İtalyan Ceza Kanununda bu konuda bir açıklık bulunmamasından hareketle, yurt dışında işlenen iftira suçu yönünden suçlanan şahsın geri alınamayan şikâyette (istanza) bulunabileceği kabul edilse dahi, bu iftira suçunun hıkukî konusunun şahsa ait menfaat olduğunu değil, fakat yurt dışında işlencn bazı suçlar yönünden devletin ilgisiz kalabileceği vakıası karşısında, sadece suçun pasif süjesi olarak değil, aynı zamanda maddî konusu veya davranışın (suçun değil) pasif süjesi ${ }^{24}$ yahut suçun dolaylı pasif süjesi²5 olarak zarar gören şahıslara, cezaî koğuşturmayı başlatmak konusunda bir imkân sağlandığını ifade eder.

Türk Ceza Hukukundaki duruma gelince: Türk Ceza Kanununun 5. maddesine göre, bir Türkün yabancı ülkede, 4. maddede yazılı cürümlerden başka, aşağı haddi üç seneden az şahsî hürriyeti bağlayıcı cezayı gerektiren bir cürüm işlemesi halinde koğuşturmanın başlaması için zarar gören şahsın şikâyeti gerekrnektedir. Böylece Türkiye'de işlenmesi

23 MANTOVANI : Diritto penale, parte generale, Padova 1979, s. 838; aymca bak LEONE: Istituzioni, vol. I. s. 337.

24 Bak. SANTORO: Manuale di diritto penale, vol. II, Torino 1962, 8. 229.

25 Bak. SANTORO : Manuale, vol. II, s. 422. 
halinde resen koğuşturulmasi gereken bazı suçlar, yabancı ülkede işlendiklerinde şikâyet üzerine koğuşturulabilen suçlar haline dönüştürülmüştür ${ }^{26}$. Şimdi, yurt dışında bir Türk tarafından işlenen iftira suçunun da şikâyet üzerine koğuşturulabilen bir suç olduğu ve şikâyet hakkının da suçtan zarar görene, yani suçun pasif süjesine ait bulunduğu düşüncesinden hareketle, zarar gören şahsın, yani pasif süjenin kendisine iftira edilen șahis olduğu, dolayısıyla suçun hukukî konusunun da devlete değil, fakat bu şahsa ait bir menfaatten ibaret bulunduğu söylenemez. Zira suçtan zarar gören kimse, her zaman suçun pasif süjesi, yani suçun hukukî konusunu oluşturan varlık veya menfaatịn sahibi değildir. Bazı suçlarda suçtan zarar gören ile pasif süjenin aymı şahıs veya şahıs topluluğu olmasına karşılık, diğer bazı suçlarda, suçu öngören norm tarafından doğrudan korunan ve suçun hukukî konusunu oluşturan varlık veya menfaatlerin sahibi olan şahıs veya șahıs topluluğundan, yani suçun pasif süjesinden başka şahıslara ait varlık veya menfaatlerin ihlal edilmesi, bir başka deyişle zarara uğratılması veya tehlikeye konulması da mümkündür. Bu ikinci nevi varlık veya menfaatlerin sahibi şahıs veya şahıs toplulukları, suçun pasif süjesi olmamakla birlikte, suçtan zarar gören şahıslardır ${ }^{27}$. Nitekim, suçtan zarar gören kavramu, ceza muhakemesi hukuku yönünden de sadece suçun pasif süjesi (mağduru) anlamında anlaşılmamaktadłr. Dolayısıyla söz konusu kavramı, ceza muhakemesi yönünden, ihtiyaca göre dar (yani suçun pasif, süjesini içerecek biçimđe) veya geniş olarak (yani pasif süje ile birlikte suç tarafından hukuken korunan varlık veya menfaatleri ihIâl edilen diğer şahısları da içerecek biçimde) anlamak mümkün ve hatta gereklidir ${ }^{28}$. Şu halde, Ceza Kanununun 5. maddesinin yurt dişında bir Türk tarafından işlenen bazı suçların, bu arada iftira suçunun koğuşturulmasını şikâyete bağlaması karşısında, iftiraya uğrayan şahsın şikâyette bulunabileceğinin kabulü, bunun iftira suçunun pasif süjesi olduğu, yani ihlali suçun esasını oluşturan varlık veya menfaatin șahsa ait bir varlik veya menfaat olduğu sonucunu doğurmaz. Iftirada sahte olarak suçlanan şansa ait menfaatlerin de ihlal edildiği kuşkusuzdur. Ancak bu menfaat suçu öngören normun varllk sebebini veya ihlali suçun esasını oluşturan menfaat değildir. Bununla beraber, daha önce de belirtildjği üzere, yurt dışında işlenen bazı suçları koğuşturma yönünden

26 EREM : Tïrk Ceza Hukuku, c. I, s. 186, 187. 
devlethi ifgisiz kalabilmesi ihtimali karşısında, suçun pasif sujjesinden başka, stgum maddi konusu veya davranışn (suçun deği1) pasî süjosi

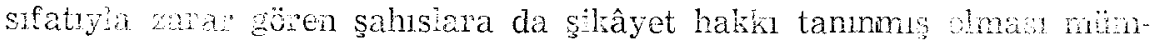

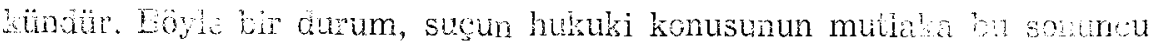

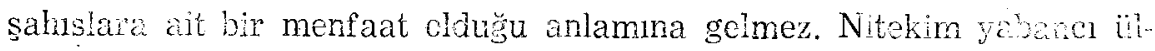

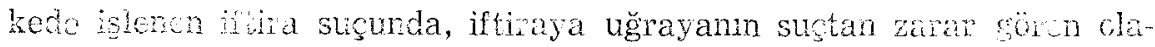

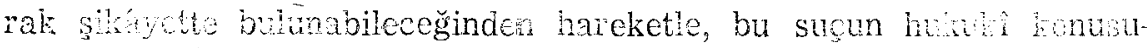

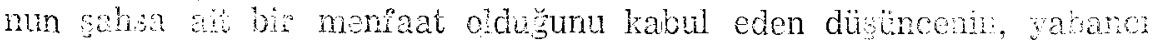

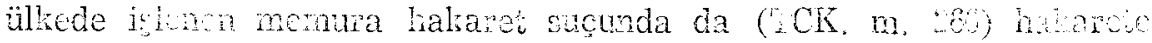
uğrayan memurui suçtan zarar gören olareł sikâyette buanbilece

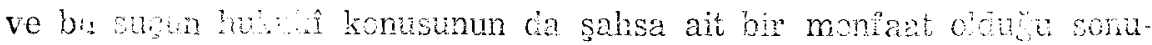
cuna vamesi g. ckir. Oysa memura hakaret sucunun yut demra iș-

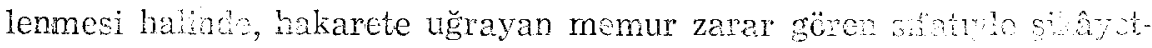
te bulunabilirse de, bu suçun hukuki konusunun devlete ait bir menfaat olduğunda kusku yoktur.

Nhayet, iftira suçunun hukuki konusumun adeletin idaresi oidugunu kabul ettikten scnra, birden çok süjenin tek bir suclama ile suclanmas: halinde suctanan süje saysmes jetra sucunun gerçeklestiöini söylemek,

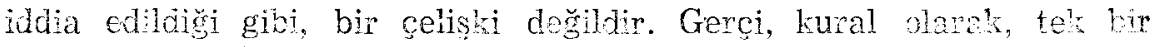
davranıştan pasif süje sayısınca suc doğması, ancak hayat, fizik bütünlük, hüriyot gibi esas itibaryle bireysel varhiklarn inhl crimis olması halinde mümkündür. Bununla beraber, tek bir davranışn belli bir süjeye ait hukukî varlı⿳̆冖̆ bircen fazla ihlal etmesi halinde de ayn sonuca, yari ihlal sayısinca suc olduğu sonucuna varmak gerelsi:. Ni. tekim tek bir suclama ile birden çok şahsın suçlanması halindo, birden çok masum şahıs hakkında yine birden cok ceza koğuşturması inkôn yaratılms ve dolayısıla devletin masum bir sahıs aleyhire ceza ğusturmasi yapmamadaki menfeati, suçlanan şahis sayisnen ihlal edilmiş olduğundan, birdeh çok iftira suçu ișlenmiş kabul edilmektedir. Ayn sekilde, tek hareketle bircten çok devlet memuruna bakeret cdilmesi halinde de, birden çok halaret suçu (TCK. m. 266) moyrdana rolmis olacaktr. Bu gibi durumlarda ancak müteselsil sticun varlıg taz tışma konusu olabilir'29.

27 Suçun pasif süjesi (mağduru) ve suctan zarax gören şahı kavramları iẹin brk. ANTOIISEI: Manuale, par. gen., s. 134; DONMMRER ERTMN : age., c. II, S. 521.

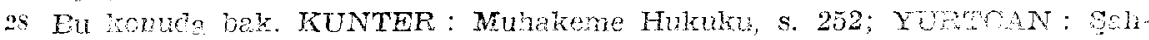
ŝ̂ Dave, Istanbul 1977, s. 104 va.

29 MANZINI : age., vol. V, s. 311, Ancak Yarg1ay'n bu gibi anumana bin

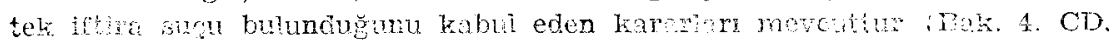




\section{2 - Kamunum itimadr.}

E'ski bir anlayış, iftira suçunun kamunún itimadını ihlal ettiğini savunmaktadır $^{30}$. Bu anlayıș benimseyen 1853 tarihli Toskana Ceza Kanunu ile 1859 tarihli Sardinya Ceza Kanunu iftira suçunu kamunun itimadina karşı suçlar arasinda düzenlemektedir ${ }^{31}$.

Ittalyan birliğinin l:uruluşuyla giderek bütün İtalya'ya yayılan ve 1889 tarihli Ceza Kanununun yürürlüğe girmesine kadar yürürlükte kalan 1859 tarihli Ceza Kanununu esas alan Pessina, kamunun itimadina karşı işlenen sahtekârlık suçlarını üç gruba ayırmaktadır. Bunlardan üçüncü gruba dahil sahtekârlık suçlarının konusu, diğerlerinden farkh olarak para, amblem veya evrak değil, fakat muhakemede isbat işlevi gören "insan sözleri"dir. Pessina, paralarda sahtekârlığın münhasıran ekonomik ilişkiler alanına girmesine, evrakta sahtekârlığın da hem muhakeme faaliyeti alanlarında hem de bu alanların dışında gerçekleşebilmesine karşılık, insan sözüne ilişkin sahtekârlığın yalnızca yargıcı aldatmak suretiyle adaletin etkenliğini altüst ettiği için sahtekârlık suçunu oluşturduğundan hareketle bu sonuncu gruba adlî sahtekârlık (falso giudiciale) adını vermektedir ${ }^{32}$.

Iftira suçunun iftira edilon kişi ve adliyenin idaresi yönünden de zararlı bir fiil olduğunu kabul eden Pessina, bu suçun, esas itibariyle ceza muhakemesi yönünden gerekli olan gerçeği değiştirmesi nedeniyle, bir sahtekârlık suçu olduğunu iddia etmektedir ${ }^{33}$.

14.3.1946 tarih E. 2144/K. 3804 sayılı kararı). Yargitay, aynı sekilde bir dilekçe ile iki kiģinin ihbar ediimesi halinde de 80 . maddenin uygulanamayacağına karar vermiştir (Bak. 4. CD. 9.4.1957 tarih ve E.2729/K. 5420 sayilı kararı).

so Bak. PESSINA : Elementi di diritto penale, vol. III, Napoll 1885. s. 229, 249,250

Bu görüşï savunan AIman hukukçular için bak. PAGLIARO: Il delitto, s. 113 , dipnot 11.

81 MANE'REDINI : Dei delitti contro l'amministrazione della giustizia, Milano 1927, s. 100 .

32 Pessina, yalan tankink ve yalan yere yenin etme suçlarnn da bu gruba sokmaktadır (Elementi, s. 229).

Ancak yazar, 1889 tarihli Ceza Kanununun yürülüğe girmesirden sonra, söz konusu suçları ve dolayısıyla iftira suçunu, bu kanunun sistematiğine uygun olarak, adliyenin idaresine kargl suçlar böllimłunde incelemektedir (PESSINA: Manuale del diritto penale italiano, parte seconda, Napoli, 1899, s. 165 vd.)

83 PESSINA : Lineamenti, s. 249, 250. 
Iftira suçunun kamunun itimadını ihlal ettiği görüşü, kamunun itimadını ihlal eden suçlar kategorisinin, hukukî ve ekonomik hayatta dürüstlüğü ihlal eden bütün suçları (bu itibarla dolandırıcılik, gitveni kötüye kullanma, cürüm eşyasını satın almak ve saklamak, hileli iflas gibi suçları) da içine alacak şekilde genişletilmesi sonucunu doğuracağı için reddedilmektedir.

Öte yandan, kamunun itimadına karşı suçlar yönünden, bazan gerçek olan bir fiili isbata yönelik bär sahtekârllk dahi suç tesskil edebilir. Nitekim Ceza Kanununun 347. maddesine göre, evrakta sahtekârlık suçları "sahih bir keyfiyetin esbabı sübutiyesini tedarik maksadiyle işlen. miş" olsa bile cezalandırilmaktadır. Örneğin, gerçek bir ödemeyi isbat etmek için sahte bir ödendi belgesi düzenlemek durumunda olduğu gibi. $\mathrm{Bu}$ şekilde düzenlenen sahte ödendi belgesi, söz konusu olayda değilse bile, potansiyel açıdan hataya neden olabileceğinden, bunu düzenleyen kimse sahtekârlık fiilini işlemistiri"s. Oysa suç belirtileri bir kimsenin gerçek suçluluğunu ortaya koymak için uydurulmuş ise, suçlanan kimsenin suçsuz olması şartı gerçekleşmediğinden iftira suçu oluşmayacaktır.

\section{3 - Adliyenin idaresi.}

Çok yaygın bir anlayıs iftira suçu ile ilgili olarak, adliyenin idaresinin korunduğunu, yani bu suçun hukukî konusunun adliyenin idaresine ilisskin ve devlete ait bir menfaat olduğunu savunmaktadır.

Ancak bu anlayıștan yana olanlar arasında bir ayırım yapmak gerekmektedir. Bir kısım yazarlar, bu suçla ilgili olarak, sadece adliyenin idaresinin korunmasını nazara almaktadırlar ${ }^{35}$. Böyle düşünenlere göre, kanun bu suç ile, haksız bir mahkûmiyete uğrama tehlikesi ile karşı karşya kalan süjenin menfaatini değil, devletin ceza adaletinin düzenli idaresine ilișkin üstün menfaatini korumayı amaçlamaktadır. Bir kere, iftira suçunun gerçekleşmesi için sahte suçlama nedeniyle bir ceza koğuşturmasının başlatılması tehlikesinin yeterli olması, kanunun korunmaya değer esas menfaat olarak adaletin iyi işlemesine ilişkin menfaati kabul ettiğini göstermektedir; diğer menfaatler korumaya değer görülselerdi ceza koğuşturmasının başlaması tehlikesi yerine hị̧ olmaz-

34 CARNELUTTI : Teoria del falso, Padova 1935, s. 3.

65 VANNINI : Manuale di diritto penale italiano, parte speciale, Milano 1951, s. 96, 97 PANNAIN : Calunnia, s. 679; CURATOLA : Calunnia (dir. pen.) Enciclopedia del diritto, vol. V, s. 818; SANTORO : Manuale, II, s. 464, 465. 
sa bunun gerçekten başlamasını şart koşmak gerekirdi. Çünkü her ne kadar koğuşturmanin başlaması tehlikesinin suçsuz şahsa da zarar verebileceği doğru ise de, bu kanun koyucunun ceza müeyyidesi ile bu derece enerjik müdahalesini gerektirmeyecek kadar uzak bir tehlikedir. Öte yandan, kendi kendine iftiranın cezalandurılması da, iftiraya uğramış olanın menfaatlerinin yerini adaletin yöneticisi olarak ortaya çıkan devlete ait üstün menfaate terkettiğini ortaya koymaktadır. Aynca iftiraya uğrayanın zararı, cezayı ağırlaştırıcı bir neden olarak öngörüldüğünden, neticenin dışında kalan bir zarardır ve bu haliyle söz konusu cürmün hukukî konusuna dahil değildir ${ }^{36}$. Nihayet bu husus, iftira cürmünü şerefin ihlalinden (Fransız ve Belçika kanunlarında olduğu gibi) veya kamunun itimadının ihlalinden (Toskana ve Sardinya kanunlarmda olduğu gibi) ibaret sayan bazı yasamlardan farklı olarak, hemen bütün modern yasamalar gibi adliyenin idaresine karşı suçlar arasında düzenleyen ceza kanununun ortaya koyduğu sistematik yerleştirmeden de açıkca anlaşılmaktadır ${ }^{37}$.

Diğer bir kısım yazarlar ise, ferdin menfaatinin de ihmal edilmemesi gerektiğini ve bu menfaatin de korumanin ve bu itibarla suçun dolayl1 konusunu oluşturduğunu ileri sürmektedirler ${ }^{38}$. Bunlar, adliyenin idaresine (aldatılması ve saptırılması tehlikesine) ilişkin menfaate öncelik tanımakla birlikte, suçsuz şahsın hürriyetinin veya şerefinin zarara uğraması tehlikesini önlemeğe ilişkin menfaati de nazara almaktadırlar.

Ancak, iftira suçunun doğrudan doğruya hukukî konusunun adliyenin idaresine ilişkin ve devlete ait bir menfaat olduğunu kabul eden her iki gruba mensup yazarlar arasinda, devlete ait bu menfaatin tam olarak neden ibaret bulunduğu, yani iftira suçunun tam olarak neyi ihlal ettiği konusunda görüş birliği mevcut değildir.

Nitekim bir anlayıs, bu suçun isbat faaliyetinin doğruluğunu, yani yargıcın kanaatini, doğuşu yönünden ihlal ettiğini savunmaktadırs9. An-

36 PANNAIN : Calunnia, s. 679; CURATOLA: Calunnia, s. 818.

s7 CURATOLA : Caluniaia, s. 818,

38 GULLO : Il delitto, s. 8; MAGIORE - age., s. 261; BOSCARELII : Il delitto, s. 41.

Bu iki tezin, özli itibariyle aynı değerde olduğu; zira bir suçun birden çok hukuki konusu olamayacağı kabul edilince, normun, doğrudan korunan menfaatin yamsıra baska menfaatleri de korumasının hukukî vralığın tesbiti yönünden önem taşımadığı ileri sürülmuştür (PAGLIARO: I delitto, s. 114, dipnot 12).

39 Pisani tarafindan savunulan bu anlayı için bak. PAGLIARO: In delitto, s. 114, dipnot 12 . 
cak haklı olarak belirtildiği üzere, suçlama, sadece ihbár veya şikâyet şeklinde ortaya çıktığında değil, aym zamanda suç belirtileri uydurma durumunda da isbat faaliyetine ilişkin değilidir. Cünkü, î̉tiı suçunu öngören hüküm, suç belirtileri uydurmayı iftira sucunu oluşturan suçlama vasitaları arasinda saymakla, bunun isbat faaliyetine iligkin menfaatten başira bir meniaati ihlal ettiğini kabul etmektedir. Aksi hajde şekli if̂tiranın maddî iftira ile yan yana konulmasinı ve her ikisi için öngörülen cezanın aynı olmasını açılamak mümkün olamazdı ${ }^{i 0}$.

İkinci bir anlayıs, iftiraya ilişkin hükümlerin, gereksiz voya yaiarsız muhalreme faaliyetini önlemeyi hedef aldlklarm kabul edertt. Ne var ki, asılsız muhakemelerle adlî faaliyetin israfı, büyük öģüce medenî ve idarî muhakeme yönünden de gerçekleşmektedir; ancak hiç kimse bu tür fiilleri cürüm veya kabahat olarak cezalandrmayl düşünmemektedir ${ }^{22}$. Öte yandan, adlî faaliyetin israfmun muhakemo gidarlerinin tazmin ettirilmesi ile de yeterli şekilde önlenebileceğini süylemck mümkündürts. Şu halde, sadece iftirann deß̧il, sụ uydumann suc sayiması da gereksiz muhakeme faaliyetinde bulunmamadali monatis açıklanamaz.

Aynı düşünceleri, iftira suçunun hukukî konusunun münhašran ceza açalcinin dïzenli yönetimindeki meníaat olduğunu benimseyen görüş ${ }^{44}$ için de tekrar etmek mümkündür.

Diğer bir anlayıs, iftira suçunun hukukî konusunun adlî faaliyeł̇in ceza müeyidelerinin yanllş tatbikine sebep olacak şekilde tahrił cdilmemesindeki devlete ait menfaat olduğunu kabul etmelitedir. Nitekin Gullo'ya göre, devlet adalet mekanizmasının boş yere çaliștırılması ne-

40 PAGLIARo: II delitto, s. 114, dipnot 12.

41 Bu anlayısi savunan yazarlar için bak. PAGLIARO : I] deitio, s. 115, dipnoí 12.

Suc uydurma, iftira ve kendi kendine iftira cürümfering, esteplz yere ada'etin diglilewini harekete gecirmiş oimayl ifade ettiklerai ve bu suchar

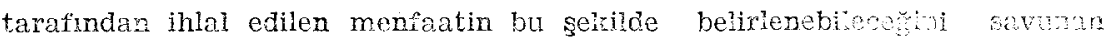
Santoro'yu da (Manuale vol. II. s. 464, 465) bunlar arasunda waymak ritinsuindür.

42 PANIVAIV: Calunnia, s. 680 .

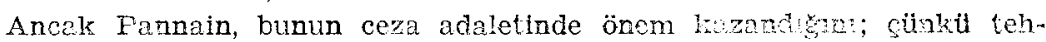
iikeli clduğunu ve bu tehlikenin. iftirada doğrudan doğruya tehince, suৎ uyourmada iae dolayl tehlike seklinde beirdiğini Leri sümelstedi. (Coluniala, s. 680).

43 PAGLIAFO: 11 delitto, s. 115 , diprot 12 ,

44 CURATOl.A : Calunnia, s. 818. 
deniyle değil, fakat bu mekanizmanın yanlıs olarak çahştırılması nedeniyle, yani iftira edenin adlî faaliyeti ceza müeyyidelerinin yanış tatbikine sebep olacak şekilde tahrik etmesinden kaygı duymakta ve harekete geçmektedir ${ }^{4.5}$. Aynı şekilde Pannain de, devlete ait menfaatin, ceza adaletinin yanlıs yöne yöneltmeye yönelik davranışlarla yoldan çlkmiş olmasını önlemedeki, bir başka değişle haksız bir mahkümiyet veya haksız bir karar (örneğin hiç suç işlememiş kimse hakkında genel af nedeniyle verilen düssme veya beraat kararı) tehlikesini önlemedeki menfaat olduğunu savunmaktadır ${ }^{46}$. Görülüyor ki, bu anlayısta ağırlık noktası, aşırı biçimde, muhakemenin sonucu üzerinde toplanmaktadır. Bu ise, iftira suçunun ortaya çlkması için sadece bir ceza koğuşturması imkânı ile birlikte suçsuz bir kimsenin suçlanmasının gerekli olduğu hususu ile bağdaşmamaktadır ${ }^{47}$.

Bir başka anlayış ise, devlete ait menfaatin savcıda bir süjenin belli bir suçun sorumlu faili olduğu konusunda bir şüpheye veya olumlu bir kanaate neden olmağa ve bir ceza koğuşturmasını başlatmağa elverişli faaliyetlerin, bunun doğru olmadığı bilinciyle gerçekleștirilmemesindeki menfaat olduğunu savunur ${ }^{48}$. Ancak iftiraya uğrayan suçsuz kimsenin menfaatinin nazara alınmaması ve koğușturmayı başlatacak savcının kanaatine ağırlık vermesi ve böylece birinci anlayıșa yaklaşması nedeniyle bu anilayışı benimsemek de mümkün gözükmemektedir.

Nihayet, doğruluğuna inandığımız anlayışa göre, iftira suçunun hukukî konusu suçsuz bir şahıs leyhine ceza koğuşturması yapılmamasindaki devlete ait varlik veya menfaattir ${ }^{49}$.

$\mathrm{Bu}$ anlayışın gerçeğe uygun olup olmadığını ve dolayısıyla devlete ait varlik veya menfaatin tam olarak neden ibaret bulunduğunu ortaya

45 GULLO : Il delitto, s. 13.

48 PANNAIN : Calunnia, s. 679 vd.

47 PAGLIARO : Il delitto, s. 115, dipnot 12

48 BOSCARELLI : Il delitto, s. 22, 24.

Yazar, maddî iftira ile şeklî iftiranın ayrı kanunî tịleri oluşturduğunu ileri sürmekte, fakat her ikisinin hukukí konusunun da aynı menfaatten ibaret bulunduğunu söylemektedir (Il delitto, s. 24).

49 Bu göruişu savunan yazarlar için bak. PAGLIARO : Il delitto, s. 114. dipnot 12.

Pagliaro, iftira suçunun hukukî konusunun suçsuz bir şahıs alevhine ceza koğuşturması yapmamadaki menfaat olduğu anlayışının gerçeğe daha yakın olduğunu kabul etmekte, ancak bu menfaatın devlete değil, bireye ait bulunduğunu ve dolayısıyla söz konusu suçun, kendi kendine iftira suçunun aksine, adaietin idaresi aleyhine bir suc saylamayacağını savunmaktadır (Il delitto, s. 115 , dipnot 12 , aynca s. 121 vd). 
koyabilmek için, her şeyden önce, söz konusu suçun iftiraya uğrayan şahsa ait bir varlık veya menfaati de ihlâl edip etmediğini, ihlal ediyorsa bu şahsî varlık veya menfaatin ne olduğunu araştırmak gerekir.

Bu konuda doğru bir sonuca varabilmek için, mevcut olmayan, yani ölü veya hayali kimseler aleyhine ihbar veya şikâyette bulunmak yahut suç belirtilerini uydurmak suretiyle iftira suçunun işlenebilip işlenemiyeceğini belirtmek gerekir. Ceza Kanununun 285. maddesinde yer alan "suçsuz olduğunu bildiği bir kimseye bir suç isnad eder yahut o kimse aleyhine böyle bir suçun. maddî eser ve delillerini uydurursa" ibaresi nazara alındığında, ölü veya hayal ürünü kimselere karşı bu suçun işlenemiyeceğini kabul etmek gerekir. Nitekim, "bir kimse" zamiri ile ilgili düşünceler"so bir yana, sadece "suçsuz olduğunu bildiği" ibaresi, mevcut olmayan bir şahıs yönünden iftira suçundan söz edilemiyeceğini göstermeye yeterlidir. Zira suçsuz olmak, sadece gerçek ve yaşayan bir şahsın sahip olabileceği gerçek ve aktüel bir oluş biçimidir ${ }^{51}$. Öte yandan, iftira suçu için öngörülen cezanin suç uydurma suçu için öngörülenden daha ağır olması da, ancak iftira suçunda, suç uydurmadan farklı olarak, iftiraya uğrayan şahsa ait bir varlık veya menfaatin de zorunlu olarak ihlal edilmesi ile açlklanabilir ${ }^{52}$. $O$ halde, önce iftira suçunda kaçınılmaz biçimde ihlal edilen şahsî varlık veya menfaatin ne olduğunu araştırmak gerekmektedir.

so Nitekim Manzini, ölu veya hayal ürlinü kimselere karģ iftira suçunun iģlenemiyeceğini, suçun "bir kimseye" yani yaşayan bir bireye lonad edilmesi gereğine dayandirmaktadir (age., vol V, s. 711).

31 BOSCARELLI : Il delitto, s. 37, 38.

52 Pannain, kendi kendine iftiranın daha hafif bir ceza lle cezalandırimasını, kanun koyucunun iftira suçu yönünden bir miktar cezayı adaletin ugradiğı tehlike için, diğer bir miktar cezayı da kendisine iftira edilenin karşlaştığ tehlike için hesaplamasına, buna karşlık kendi kendine iftira yönlinden sadece birinci tehlikeyi nazara almasina dayandırıp bundan iftirada bireye ait bir menfaatın de korunduğu sonucunun çıkarılamayacağını ileri sürmektedir. Yazara göre, kendi kendine iftiranın iftiraya nazaran daha az bir ceza ile cezalandırılmasını haklı kılan husus, birey yönünden tehlikenin yoklugu deģil, fakat bu suçun içkin ağırlığının daha az olması ve kendisini bir mahkumiyet tehlikesi ile karģ karşya birakan kimsenin sübjektif durumudur. (Calunnia, s. 679).

Bu nedenlerin kendi kendine iftira suçunun daha az bir ceza ile cezalandırılmasını haklı kılacağı kabul edilse bile, aynı nedenlerin suç uydurma cürmu için iftiraya nazaran daha hafif bir cezanın öngörülmüs olmasını açılkamaya yetmeyeceginde gुliphe yoktur. 
Daha önce de değinildiği üzere, bir kısım yazarlar iftira suçunun daima iftiraya uğrayan kjmsenin şerefini de ihlâl ettiğini savunmaktadırlar. Ancak bu görüşe katılmak mümkün değildir. Bazı kabahat niteliğindeki suçların (özellikle trafiğe ilişkin kabahatlerin) veya bazı siyasî veya dinî suçların isnad edilmesi halinde, haksız yere suçlananın şerefinin ihlal edildiği söyleneme $z^{53}$. Bir başka değişle mahiyeti veya saikj nedeniyle toplum şuurunun kınanabilir kabul edmediği bir suçun isnadı söz konusu olduğundạ, bireyin şeref varlığı ihlal edilmiş sayılamaz ${ }^{54}$.

Her ne kadar, hukuka aykırılığın daima şeref varlığının hukukî an. lamda ihlalini de beraberinde getirdiği, hatta belirli bir siyasî - felsefî anlayıștan hareketle devletin ahlâkiliği tesbit etme fonksiyonunu elinde bulundurduğu (etik detlet) ve bu nedenle hukuka aykirı bir fiilin isnadinın şerefi ihlal etmemesinin mümkün olamayacaği, öte yandan iradî ceza hukuku (Willensstrafrecht) prensiplerinin vasitaya (yani ceza adaletini gayri meșru şekilde harekete geçirmeye) değil, suçlamanın amacına (yani şeref varlığının hukukî anlamda ihlaline) önem verdiği ileri sürülmüş ise $d^{55}$, bu iddiaların inandırıcı olmadıklarını ortaya koymak hiç de güç değildir. Bilindiği üzere devlet, șeref varlı̆̆ını korumak istediğinde, devlete ait değerler düzenini yegâne değerlendirme aracı olarak nazara almamakta, aksine şeref kavramını topluma özgü degerler düzenine dayandırmaktadır ${ }^{56}$. Şu halde, iftiranın şeref varlığına karşı bir cürüm sayllp sayılamayacağı sorunu, siyasî-felsefî nitelikte bir soruna bağlanamaz. Etik devlet anlayışı benimsense dahi, bu, devletten farklı etik değerlendirme kaynaklarının gerçekten var olduğunun reddedilmesini değil, sadece diğer değerlendirme kaynaklarının vardıkları sentezin devletin değerlerine dahil edilmesini gerektirebilir. Şu halde bir kanunî tipin, kendi içeriğini belirlemek için toplumsal nitelikte bir değerlendirme ölçüsüne yollamada bulunması imkânı, bu durumda dahi mevcuttur ${ }^{57}$.

Öte yandan davranışın amacının, hukukî varlığın belirlenmesi yönünden esaslı bir unsur olduğu hususu, bununla bireyin somut amacinin değil, fakat kanun tarafından tipikleştirilen amacın kastedilmesi şartıyla doğrudur. Ancak bu kural iradî ceza hukukunun prensiplerine bağlı

ss PAGLIARO: $\Pi$ delito, s. 118.

44 BOSCARELLI : Il delitto, s. 39, 40.

s5 Bak. PAGLIARO : II delitto, s. 119.

so Bak. SANTANGELO : Concetto ed accertamento dell' ofesa all'onore, Scritti De Marsico, vol. II, Milano 1960, s. 501.

st PAGLIARO : Il Delitto, s. 119. 
değilcir; çünkü söz konusu kural suç teşkil eden davanışn larifini yö-

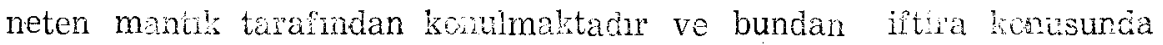
herhangi bir sonuç çıarmak mümkün değildir. Nitelkim daha önce de belirtilaiğ gibi, iftiraya ilighsin kanunî tip yönünden kamunun itimadnun, bireyin ve adliyenin idaresinin ihlali, fail tarafindan gerçeirleşirilen amege sucoin (hareketin) ayn sahnasma liskinis, yani har us ihlal de ayn anda gerçekleşmektedir. Dolayisıyla amecn vasitaya üstüniüğ pren pioi burada uygulanamaz. Fail, somut slàaz, seglanam

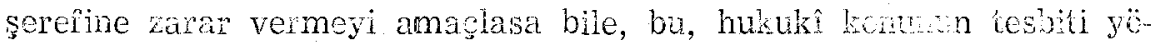
nünden önern taşmáz. Ayn sekilde failin, somut olarm, adiyyi bos yere uợraştırmayı veya adlî faailyeti saptrmayı yahut daha genel bir iradey süjeler arası iliskilerdeki güvenin azalmasin anagladiğnda da curum farksizdir ${ }^{58}$.

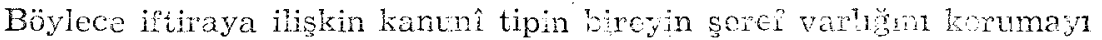

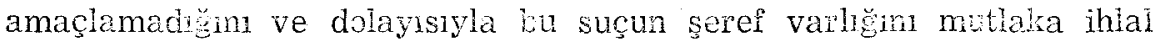
etmedighini ortaya koydutan sma, aju scyin iftira chlon cieyhins açlacak loğbbumann sorucu carak zarara ugravabilecek bireysel varhk veya menfaatler ig̣in de söylenemiyeceğini belintmek gevelin.

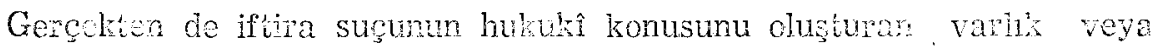
menfaat, sadece iftiraya ugrayan aleyhine bir koğuştumanin baslaması imkânını doğuran bir davianıs dolayısiyla zarara uğratılabilen bir

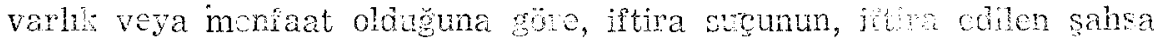

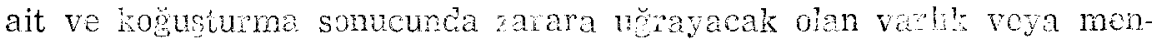

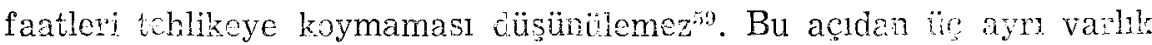
veya monfaat söz konusu olabilmektedir. Bunlar, cezể toğustumaya tabi clmamadaki, mahkium olmamadaki ve infara tahi tudulmamadaki varhk veya meniaatlerdir. Ceza adaletinde 1slah foniss acu aci verme fonksiycmuna (funzione affilttiva) üstünlük kazandiğ süroce, üe varluk veya menfaatin, suçlu kimseler yönünden de movest olnğ̣ kabul edilebilir. Ancak bir suçlunun söz konusu olması halinde, bu bireysel varhk veya monfaatler devlèin üstin varlık veya monfanti karsismda etkisiz hale gelir; oysa bir sucsuz söz konusu olduğunda ayn şoyi söylemek mümß̈̈̈ değildir. A'ssine suesuz kimsenin koğusturulmamasnda veya mahlsum edilmemesinde yahut haklinda bir cozann infaz edilmemesinde devletin de menfaatı vardir. Öyle ise, bu varık veya menfaatlerin her hirini cezaî koruma altına almak soyut olarak mümkündür ${ }^{f 0}$.

68 PAGIIARO: Il delitto, s. 119, 120.

5 BOGCAFEILI : $\pi$ delitto, s. 41.

60 PAGLIARO : Il delitto, s. 120 
Türk Ceza Kanununun iftiraya ilişkin kanunî tip ile devlete ait hangi varlık veya menfaatı koruduğunu ve doiayısıyla ’̧u suçun hukukî konusunu oluşturan varlık veya menfaatin neden ibaret bulunduğunu tesbit edebilmek için söz konusu kanunî tipin bireye ait bu üç ayrı varlık veya menfaatten hangisini nazara aldı̆̆ın belirlemek gerekmektedir.

Türk Ceza Kanunu, suçsuz şahsın hürriyeti bağlayıcı bir tedbire tabi olmamadaki, mahkûm olmamadaki veya infaza tabi olmamadaki menfaatini sad̉ece özel şiddet sebepleri yönünden nazara almaktadır. Nitekim 285. maddenin 2. fikrasinda iftira olunan kimsenin tutuklama gibi hürriyeti bağiayıcı bir tedbire tabi olmasına, 3 , 4, ve 6 . fikralarında mahkûmiyet hükmü ile verilen cezanın ağırlı̆̆ına ve nihayet 5 . fıkra. sinda da mahkûmiyet hükmü ile verilen cezanın infazına göre özel ağırlaştırıcı nedenlcr öngörülmektedir. Ancak kanunun hürriyeti bağla. yıcı bir tedbirin uyģulanmasını, mahkûmiyet hükmünün içeriğini ve cezanın infazını sadece ağırlaştırıcı nedenler yönünden nazara almış olması, bütün bunların söz konusu suçun varlık sebebini oluşturmayacağınl göstermektedir ${ }^{61}$.

$\mathrm{Bu}$ durumda geriye sadece suçsuz bir şahsın ceza koğușturmasına tabi olmamadaki varlık veya menfaati kalmaktadır. Iftiraya ilişkin kanunî tipte, devlete ait varllk veya menfaatin yaninda, korunan ve söz konusu suç tarafından daima ihlâl edilen (en azından tehlikeye konulan) bireysel varlık veya menfaatın bu olduğunu, iitira suçunun oluşması için isnad edilen suç yönünden koğuşturulabilirlik şartımın yeterli bulunması da açıkca ortaya koymaktadır.

Devletin adlî yetkisini gerçekleştiren organların suçsuz kimseler aleyhine cezaî koğuşturma yapmaması hukuk devletinin temel niteliklerinden biri olduğundan ${ }^{62}$, bu gibi kimselerin haksiz yere ceza koğusturmasıyla karşı karşıya kalmamasında devletin de menfaatı olduğunda kuşku yoktur. Bu konuda ferde ve devlete ait varlık veya menfaatlerden devlete ait olana üstünlük tanyan kanun koyucu, iftira suçunu adliye aleyhine suçlar arasında düzenlemiştir. Şu halde iftira suçunun hukukîi konusunun, suçsuz bir kimse aleyhine koğuşturma yapmamadaki devlete ait varlık veya menfaat olduğunu söylemek mümkündür. İftira suçunun, daha önce de belirtildiği gibi, haksız yere bir ceza koğuştur-

61 Italyan Ceza Kanunu, mahkümiyet hükmünün içeriği dışında kalan hususları (hürriyeti bağlayıcı bir tedbirin uygulanmasını ve cezanın infazını) ağırlaştımcı sebepler yönünden dahi nazara almamıştır.

62 Bu konuda bak. EREM : Ceza Usulü Hukuku, Ankara 1978, s. 494 vd. 
masına maruz kalmamaya ilişkin ve bireye ait bir varlık veya menfaati de daima ihlal ettiği şüphesizdir. Bu durum, devlete ve bireye ait olan ve yukarıda belirtilen varlık veya menfaatler arasındaki ilişkinin normal bir sonucudur.

Ancak, iftira suçunun birden çok varlık veya menfaati ihlal etmesi, bu suçun özel ve esas hukukî konusunun, yukarıda belirtilen şekilde devletin adlî faaliyete (adliyenin idaresine) ilişkin varlık veya menfaati ile aynileştirilmesinin doğruluğunu etkilemez. Yeter ki, suçun bukukî konusu kavram, belirli bir suçun işlenmesi ile ihlali kaçınımaz olan bütün varlık veya menfaatleri kapsayacak şekilde tamamen biçimci ve tasvirj bir kavram haline getirilmek ve böylece bu kavram, esasın olusturan unsurlardan yoksun kılınmak istenmesin ${ }^{68}$. Birden çok varhk veya menfaati ihlal eden bir kanunî tip karşısında, suçun hukukî konusu olarak kabul edilebilecek bir tek: varlık veya menfaatı belirlemek için, birinci derecede veya esas olarak korunan bir varlık veya menfaat ile sadece ikinci derecede veya dolaylı olarak korunan diğer herhangi bir varlık veya menfaat arasında ayrım yapmak gerekir. Böyle bir ayırım yönünden, özellikle ceza kanuru gibi, suç yaratan normların büyülk bir çoğunluğunun her bir norm tarafından öngörülen suçun hukukî konusuna göre tasnif edildiği bir kanun söz konusu olduğunda, suçu öngören normun kanundaki yerinin kural olarak belirleyici bir nitelik taşıdığında şüphe yoktur ${ }^{64}$.

* BOSCARELLI : Il delitto, s. 41, 42

64 Bak. SABATINI : Titoll dal primo al settimo del libro secondo (Codice penale illustrato articolo per articolo); Vol. II, Milano, 1934, s. 6; GRISPIGNI : Diritto penale italiano, vol. II, Milano 1952, s. 41; PISAPLA: Introduziane, s. 81 vd., 94; PANNAIN : Manuale di diritto penale, vol. I, par. gen, Torino 1950, s. 35; BOSCARELLI : Il deritto, s. $42,43$. 